\title{
Economic Partnership Agreement between West Africa and the European Union in the Context of the World Trade Organization(WTO) and the Regional Integration Process
}

\author{
Salif KONé \\ University of Cocody/Researcher in CIRES
}

\begin{abstract}
A new cooperation Agreement has been signed between the European Union and the 77 ACP Countries in Cotonou (Benin) on June 23rd 2000. A point of this agreement is regarding a new trade cooperation between these different countries in districts (or regions) gathered and the European Union, based on a preferential reciprocal liberalisation. This agreement is intervening in the context of globalisation, the multilateral trade liberalization, the regionalization, the renewal of regional integration processes and, the multiplication of the internal conflicts in Africa. This paper ask if is the economic Partnership Agreement able to take into account the needs for development of the ACP countries in the strict frame of the region Western Africa The thesis developed herein want to demonstrate that the principles of the APE do not allow to take really the needs of development for the countries of the region Western Africa: in consideration to the context, the APE characteristics, the structural and institutional rigidities' of the economies of these area.
\end{abstract}

- JEL Classification: F02, F13, F15

- Key Words: WTO, regional economic integration, economic partnership agreement, trade negotiations, development, West Africa Region

\footnotetext{
*Corresponding address: Salif KONÈ: Professor-Assistant at the University of Cocody (Abidjan, Côte d'Ivoire), 08 B.P. 1295 Abidjan 08, France e-mail: salifkon@yahoo.fr.

(C2010-Center for International Economics, Sejong Institution, Sejong University, All Rights Reserved.
} 


\section{Introduction}

A cooperation agreement has been signed between 77 ACP countries of Africa, of Caribbean and Pacific ${ }^{1}$ and the European Union in Cotonou (BENIN) on June 23rd 2000. This agreement, following the Lomé conventions', has been concluded for 20 years with a clause of revision all 5 years as well as a financial protocol for each quinquennial period. ${ }^{2}$

By this Agreement which came in force on April 1st 2003, the ACP countries and the European Union agreed new trading agreements, called economic partnership Agreement that must be compatible with the rules of WTO. That is why; the ACP countries in region grouped in regions and the European Union have decided the introduction of reciprocity into the preferential trading relations.

Three main reasons have been called up to justify the introduction of this reciprocity in the cooperation ACP countries and European Union. First, the necessity to re-form an ineffective system (economical argument). In fact, the assessment of the relations between the ACP Countries and the European countries was globally considered disappointing. The conventions of Lomé did not prevent the marginalization of the ACP countries in the world Trade. They did not prevent either the fall of the foreign direct investment of the European Community in the ACP countries; they did not allow a diversification of the exported products. Second comply with the rules of WTO (juridical argument). To set up reciprocal preferences within the framework of agreements of free trade or to offer the same commercial preferences to all the developing countries (the case of the European GSP (generalized system of preferences) enhanced. The ACP countries and the European Union were faced with a complaint of Latin - America countries for violating the clause Most Favored Nation. Then the necessity to maintain a good relationship between Europe and the ACP Countries (political argument). Europe would not like to see its relationship with the ACP Countries dissolving in the general multilateralism while it remains the largest trading partner and the largest donor of the region. For example, over period 2002-2004, the Western Africa Region exported worm Europe approximately $29 \%$ of its total exports and imported Europe $33 \%$ of the total of its imports.

'The ACP Group includes now 79 countries, after the entrance of Cuba and Belize in 2003.

${ }^{2}$ The first revision of the agreement occurred in 2005 after negotiations launched in May 2004, at the council of ministers of ACP Countries and E.U in Gaborone which ended in Brussels, on February 23, 2005. 
The posted objective of this new agreement is the economic and social development in order to reduce and at term, to eradicate poverty. The introduction of reciprocity to allow the creation of competitive conditions thanks to trade liberalization and accompanying measures .(upgrading of enterprises and financing the development needs of the countries and those of the ACP Countries .

These agreements should be the result of negotiations between both parts first, with the all ACP Countries, and then at the regional level, had to be concluded, latest for the End of December 2007, according to the exceptional exemption from the clause of the Most Favored Nation obtained in Doha (Qatar) in 2001.

But the negotiations for the establishment of these new trade agreements are taking place in an international context marked by the globalization, the regionalization and especially the multilateral liberalization of trade directed in the sense of development (Development program of Doha). They were thus confronted with requirements of development which have prevented the signature of agreement between all ACP countries, grouped in region and the European Union. However, certain countries signed individual agreements with the European Union. Certainly these agreements are qualified as intermediaries in the optics of the signature of interregional agreements, but they raise the question of the future of regional integration with the E.P.A. More generally fact puts the question of the capacity of these new agreements to take into account the needs for development of the ACP Countries. Indeed, in the recent years, regional economic integration is recognized as an essential component of any policy of integration into the global economy and economic development especially in the context North-South relations. $^{3}$

This work raises the question of the ability of the EPA to take into account the needs for developing of the countries within the strict framework of the West Africa Region In particular, the objective of this work is to provide answers to the question of capacity prodevelopment of EAP in the context of the World Trade Organization and regional integration in West Africa.

The thesis developed in this paper is that the principles of EPA do not allow to take into account really the needs of development of the countries of the region Western Africa considering the characteristic losses of the EPA and the structural and institutional rigidities in the economies of this region.

${ }^{3}$ Refer to Regnault and Deblock - 2006 for a detailed analysis of the causes of reconnexion NorthernSouth. 
The rest of this paper is organized as follows. In Section II, we present the characteristics of future trade agreements (EPA). Section III examines the interaction between the rules of WTO and EPA between West Africa and European Union. Section IV examines the interactions between EPA and the process of regional integration in West Africa. In section IV are analyzed the constraints which arise the development of Western Africa by the trade.

\section{The Introduction of Reciprocity}

The introduction of reciprocity aims at operating a radical change in the commercial relation between the ACP Countries and European Union by obliging ACP countries to delete or reduce their trade barriers (tariff and non-tariff) on their imports from European Union, contrary to Lomé conventions.

\section{A. Objectives}

EPAS are based on a number of objectives (Cotonou agreement, Title II, Chapter 1, article 34), basic principles (Cotonou agreement, Title II, Chapter 1, article 35) from which rules, modalities (Cotonou agreement, Section 2, Chapter1, Article 36) procedures (Cotonou agreement, Section 2, Chapter 1, article 37) and roadmap for the negotiations $\mathrm{EU}$ and $\mathrm{W}$ are set.

Thanks the experience of Lomé conventions, the ACP countries and E.U were assigned to the future economic partnership four main objectives: (1) a progressive and harmonious integration of ACP countries in the global economy while respecting their political choices and priorities in subject of development; (2) the full participation of ACP Countries in world Trade by adapting to the new conditions of international Trade; (3) the creation of a new trade dynamics and the stimulation of investments between the different parties; (4) the perfect conformity with the rules of the WTO.

\section{B. Principles}

Economic Partnership Agreements are based on four (4) basic principles: (1) the partnership: EPAS are partnership agreements involving rights and obligations of both sides; (2) regional integration: it is an effective way to stimulate the integration into the global economy; (3) Development: First of all, EPAS are developing instruments; (4) the link with WTO: EPAs are not an end itself but a step towards to facilitate the integration of the ACP Countries into the global 
economy.

However a privilege is granted to the LDCs (less advanced countries). European Union with the initiative "All except weapons" grants to the LDCs a completely free access to its market for the native products of these countries. Those are not directly affected by the EPAs. In the same way, the small insular developing countries profit from special attentions.

\section{The Characteristics of an Economic Partnership Agreement West Africa (WA)-European Union (EU)}

By analysis, EPA has fourth main characteristics. Firstly, there is an agreement of preferential free trade. In particular, there is an agreement establishing a free trade area which exceeds the only commercial framework; it embraces relted fields with the trade such as the governments' contracts. Secondly, it is a discriminatory agreement, because of his preferential character. Also, it excludes other developed nations that those belonging to the European Union and the non -ACP countries. It also excludes any other country outside of West Africa or any country in West Africa not having agreed to sign the EPA. On the opposite, West Africa countries are excluded from all the others EPAs signed between E.U and the other ACP Countries with all the developing countries. Thirdly $y_{2}$ it is a mixed-type preferential agreement, insofar as it implies at the same time developed countries and developing countries. In the context of West Africa, it innovates despite the existence of the agreement NAFTA (North American Free Trade) between Mexico (developing country), Canada and United States of America (developed countries) so much the difference between the level of development of the two blocks is high (see annex, table 1). Fourthly, it is an agreement negotiated over a long period. The control and the management of the negotiations require, in this case, technical, financial, human capacities as well as a coordination capacity very high .Moreover, it adds the need for a holistic view of their commercial and economic development for this period overlaps the period of negotiations at the WTO.

In summary, the EPA requires the ACP countries to delete (or reduce) tariff and non-tariff barriers on their imports from the European Union. In return, the European Union is committed to strengthen their preferential tariff and non-tariff commitments to products from the ACP countries. In addition, the Union undertakes to take into account social and economic considerations to facilitate their economic development. However, this liberalisation process is done by grouping the ACP step by region. Thus, several issues arise. In particular, in the 
context of these negotiations, characteristics of the economies of countries of Africa West and issues, the question of the capacity of such an agreement to actually promote economic and social development sustainable West African countries arises.

\section{Economic Partnership Agreement and the WTO}

The establishment of an EPA between the West Africa region and the European Union will promote the sustainable development of West Africa region by their progressive insertion into the multilateral system if the process of stowing can be less expensive to the West Africa countries that this of WTO . Accordingly, three aspects of the problems of EPAs are analyzed: (a) compatibility with the rules of WTO; (b) costs and efforts of the negotiations; (c) right to the development in term of flexibility of the rules of the agreement (or special and differentiated treatment).

\section{A. The Economic Partnership Agreement Conformity with the WTO Laws}

The compliance with the rules of WTO, one of the main reasons of the introduction of reciprocity into the preferential relations between the ACP countries and the European Union may not be possible. Doing so, one of the best ways to reach the development objectives of ACP countries in general, those of West Africa in particular, may not be usable.

Indeed, the cornerstone of the multilateral trading system, under GATT as that under WTO is the principle of non-discrimination in the international exchanges. This principle is embodied in the clause of the Most Favored Nation (MFN). EPA between West Africa and European Union, following the example of other ACP regions, is a preferential trade agreement, violates the MFN. From this point of view, it will not be fully compatible with the rules and agreements of WTO. This can cause reactions from other members of WTO, from developing countries not involve, and from other ACP Countries questioning some advantages obtained by those of West Africa. Indeed, by analyze, an EPA West Africa - European Union is above all a preferential agreement of free Trade and therefore discriminatory. Also, it is exclusive to the signatories' countries. It submit trade relations between European Union and the West Africa countries to an institutional, regulatory and legal frame which only benefited to the stakeholders. In these conditions, complaints against an EPA between West Africa and European Union for violation of clause MFN will not be surprising. 
But, since it will be a free trade area, the West African countries and the European Union will wish to invoke the Article XXIV (territorial applicationborder traffic customs unions and free exchange area of GATT 1994, Part IV) of GATT 1994, Part IV of the GATT of 1994 (Trade and development), the Enabling clause, as well as the Article V and V bis of the General Agreement on Trade Services or GATS. ${ }^{4}$ These articles and clauses allowing the non-application of the MFN clause, under certain conditions.

However, the compatibility of the EPA with the rules and agreements of WTO can turn out difficult to defend. Indeed, in the case of an EPA, West African countries and European Union, the invocation of these capacities of the texts of WTO can be confronted with problems of interpretation (subparagraph $\mathrm{c}$ of paragraph 5, subparagraph a.i and b of paragraph 8 of articles XXIV of GATT 1994) and with the problems application's fields (the clause of enabling, articles V and $\mathrm{V}$ bis of GATS).

Regarding the Article XXIV of GATT 1994, the interpretation of paragraph 5, subparagraph c, of paragraph 8 , subparagraph a.i can raise a problem. Indeed, with the paragraph $5 \mathrm{c}$, this is acknowledging the need for a transition period .However, this transition period is not clearly determined. It is simply stipulated «a reasonable delay». In that case, the question is the transition period of 12 years (2008-2020) proposed by the European Union, is it compatible? Is it not too short for developing countries with the very rigid economic structures like the ACP Countries in general, those of the West Africa, in particular?. It is obvious that when this transition is being negotiated through the special and differential treatment within the framework of the Doha program, in terms of paragraph 8 , subparagraph a.i and b, its interpretation raises a problem for the ACP countries.

Regarding the Article XXIV raises the problem of interpretation of the concept (Main part of commercial exchanges). Not only this concept can be variable thus ambiguous, but no indication is given as for the way of measuring the exchanges. The twin problems of interpretation may cause compatibly problems with the EPAs. Under the economic partnership agreement signed between South Africa and European Union in 1999, it is stated that the free trade area will include $90 \%$ of products traded between both partners. By taking into account the difference of development level, we finally have $95 \%$ products realized, by the European Union

\footnotetext{
${ }^{4}$ General Agreement on Trade in Services (GATS) concluded in Marrakech at the end of the Uruguay Round. It is the in services domain. It defines the rules of world trade in services domain.
} 
(more developed) and 86\% for South Africa (a developing country).

Regarding the case of the region West Africa, the problem is determining the optimal level of asymmetry to be introduced. The degree of this asymmetry will it be $10 \%, 20 \%, 30 \%, 40 \%, \ldots$ By the game of the sensitive products and the special products, there will be no liberalization to $100 \%$, either towards the European Union or towards that of the West Africa Region. Let us suppose that the rate of liberalization of the European Union is $95 \%$ (as in the case of South Africa).If the degree of asymmetry to be introduced in the liberalization of the products within the frame of an EPA is $40 \%$, that would mean that the West Africa Region will liberalize only ( $95-40=55 \%$ ) of its products. The question which arises is thus triple. First, on which basis determined the asymmetry between European Union and West Africa? Then, being given the appropriate base, the level of asymmetry required, will it be accepted from the European Union? Finally, if a level of asymmetry is adopted, how will it be accepted by the WTO and its members, specially the developing countries non ACP? Hence the importance of waiting for negotiations clarifying the concept of "substantial Trade».

The clause of Enabling, although authorizing the creation of regional trade agreements under certain conditions, its invocation runs up against the fact that it was conceived for non mixed trade agreements whereas the EPAs are mixed type agreement of free trade. From this perspective, the EPAs are not fully compatible with the rules of the WTO.

However, regarding the Article V and V bis of the GATS, they fully take into account the flexibility wanted by the special and differentiated treatment which one can call up in favor of an EPA between the West Africa region and the European Union. However, theses articles concern only the trade of the services while the EPA concerns the services, the agricultural produces and non agricultural.

Moreover, some rules of the WTO by which compatibility may intervene are prone to negotiation, so that their next forms are not yet known. In his column "Rules of the WTO", paragraph 29, the Doha declaration stipulates that "we also agree to negotiations aimed at clarifying and at improving the disciplines and procedures envisaged by the existing provisions of the WTO which apply to the regional trade agreements. The negotiations will take account of aspects of the trade agreement relating to the development". It is what makes say Bilal (2002) which it acts a moving target. Certain authors find however, in this fact, a possibility to make compatible the EPAs with the rules of the WTO. Under these conditions the EPA appears more as a strategic choice that a question of conformity 
with the rules of WTO. This view is reinforced by the fact that to date, no trade agreement ratified at the WTO has been considered to be compatible with its agreements.

Thus to make compatible an EPA (West Africa- European Union) to the WTO rules, it could be essential that a coalition is born between the ACP Countries and European Union. That underlines other question of funds to know the capacity of these regions to define with European Union the subjects of mutual interests. The European Union and West Africa are far from having the same concerns on many subjects in negotiation with WTO, du to the very important well off development but also to very divergent interests. Thus, the conformity of an EPA West Africa European Union remains to be acquired.

Behind the idea of compliance with the WTO rules, there is an objective of development of the ACP Countries through two main mechanisms. First, it aims at stabilizing the framework of trade cooperation, in order to reduce uncertainties and to ensure the foreseeability of the rules of the cooperation. Then, it aims to avoid the costs bound to the treatments of the disputes for violation of MFN clause. Uncertainty, on the EPAs regionalized, compliance with the WTO rules calls into question the use of reciprocity as a development tool.

\section{B. The Economic Partnership Agreements, the WTO and the Right to Development}

An EPA between the West Africa region and the European Union is by definition a set of binding commitments. It is to expect that the installation of an EPA between the West Africa region and the European Union leads to a situation in which the Countries of the region have less flexibility in term of economic policies than those offered by the provisions of the WTO rules and agreements. The European Union aims at the conformity of the new trade agreements with the WTO rules through the case-law based on its own experiences.

In the Framework of negotiations West Africa - European Union, there is no guarantee that the texts of the agreement will be as (or more) flexible than those of the WTO, in consideration of the development gap. The experiment shows that these interpretations can constitute a brake for the development for the West Africa Countries because they reduce the impact of the Differential and More Favourable Treatment. According to COMAS (2007), for example, the literal interpretation of article XXIV of WTO that makes the European Union of it, is more restrictive than that done by the ACP countries, regarding the taking account of the aspect of 
development. In its temporary agreement with the Ivory Coast and Ghana, the European Union the terms (Main part of the exchanges) of Article XXIV, according to its own experiences. This interpretation gives a degree of openness of $80 \%$ of the total trade for Ivory Coast and Ghana as against $100 \%$ for European Union. The difference of $20 \%$ was reserved for sensitive products. The relevance of this interpretation in temps of effective consideration of development gap remains to be proven. The same applies as regards the interpretation of the concept "reasonable delay" in Article XXIV. There is hardly to bet that the interpretation of European Union is essential in these negotiations because of a balance of power favorable to her due to a development gap too much pronounced. (see Table 1). By the observation of this table, we realize the variation of the development levels of the West Africa region and the European Union.

Even, in the hypothesis of an agreement with the contents favorable to the countries of West Africa region, ${ }^{5}$ considering the primacy of the WTO rules in the institutional frame of this agreement, the multilateral liberalization reduces de facto the benefits to the preferential liberalization by reducing the rooms for maneuver. Any thing constituting an erosion of preferences. From a theoretical point of view, in a purely commercial optics, the participation in an EPA is less advantageous that a multilateral and unilateral commercial opening. The main reason is that an EPA, because of its discriminatory character, reduces the selection of the best companies to supply the domestic markets of West Africa Countries. By definition, an EPA consists in proposing a privileged and priority access to the Enterprises of European Union on the markets of West Africa region. Under these conditions, for identical products, it will not be necessarily the best global companies (more efficient) that will supply the markets of the West Africa region. The superiority of the multilateral and unilateral liberalization of the exchanges, by the establishment of a customs union has been proven by Vanek (1964) and Venables (1999) for the world.

The problem of erosion of the preferences can be put in perspective for the right to development. By giving a preferential access to ACP countries on the european markets for certain products within the frame of Yaounde and Lomé agreements, the European Union would provide the opportunity to ACP countries to build competitive positions and therefore comparative advantages over other developing

\footnotetext{
${ }^{5}$ The agreements signed by Cote d'Ivoire and Ghana tend to prove the contrary. The EU interpretations about the World Trade Organization are based on their own experiences and notably on the agreement signed with South Africa. That interpretation is more restrictive than the one on the West African region.
} 
countries of similar productive structures and no benefiting of such preferences. By this point of view, rules and agreements of the WTO, because based on the clause of Most Favored Nation, dilute these preferences.

It would be therefore attempt to conclude an erosion of preferences and to consider an EPA, because being a discriminatory agreement for mutual access to markets of the partners, is a solution to this erosion. However the issue of erosion of the preferences is not a simple question. Its evaluation requires the knowledge of the advantages of the preferences of the West Africa Countries with regard to developing countries not ACP but also ACP.

The state of these advantages also depends on the various cooperation agreements between the European Union and the other countries or regions in development non ACP, in their intensity and their amplitude. For example, the existence of an agreement of cooperation between European Union and Mercosur contributes to reduce the preferential margins of West Africa Countries under the Lomé Convention, but nothing says either that an EPA would allow to limit this erosion of the preferences.

\section{Costs of the Negotiations}

From a purely technical point of view and beyond the legal considerations mentioned above, raise political difficulties bound to the efforts required to the West Africa Countries concerning coherence, coordination, efficiency of the actions, strategies , economic and commercial policies. The installation of an EPA West Africa - European Union raises question of human, financial, time costs. These questions arise on 3 levels on the process of installation: preparations, subjects and diaries of the negotiations.

Regarding the subjects of negotiations whether the program Doha Development Agenda (DDA) or the EPA West Africa - European Union, they are different, many and do agree on several points. In this context, the West Africa countries have to plan, at once, coordinate, make coherent and need to have a global but precise vision of their strategies of negotiations and their economic and commercial polities. Such efforts require, at the same time, human capital, skills and expert testimonies of very high levels, important financial volume and time. These conditions are far from being filled by the West Africa countries, consisting of developing countries: (Ivory Coast, Nigeria and Ghana), of least developed countries (LDC) but coastals (Benin, Togo, Guinea, Liberia, Sierra-Leone, Mauritania, Cap-Verde, Guinea-Bissau and Senegal) of least developed countries 
landlocked (Mali, Burkina Faso, Niger and the Gambia). In short, apart from the three developing countries of West Africa that are Nigeria, Ivory Coast, Ghana, it is clear that the financial, human costs that require such negotiations are outside capacities of the other countries.

These problems of human, financial and time costs bound to the negotiations of an EPA are still worsened by the fact that the negotiations within WTO, besides the convergence on several subjects, take place in the same periods; there is, thus, overlapping of schedule. The problems bound to the coordination, the control, the coherence and the determination of the strategies of the economic and commercial polities are only worsened.

Furthermore, the inclusion of some subjects in the context of the establishment of an EPA, West Africa-European Union, may be problematic from the perspective of developing countries in West Africa. Subjects such as the competition and the business, the procurement contracts, the environment and business are sensitive subjects for the development of these countries, because of the weakness of their institutions and the rigid structures, the ability of ACP countries to implement and to follow commitments in such areas is very limited. Doing so, nothing allows to ensure that these countries can conceive and implement agreements which can support their development in these domains. In the same way, nothing allows to ensure that these countries can benefit of the provisions framing these agreements in spite of the programs of upgrade.

In conclusion, because of its discriminatory nature, of the overlapping of periods and subjects of negotiations with those of the Development Agenda of Doha, the establishment of an EPA, West Africa-European Union, can not be prodevelopment.

\section{EPA and the Process of Regional Integration in West Africa}

The place granted to regional integration in the future economical partnership agreements between European Union and the ACP countries is defined in section 3 (regional cooperation), Part 3 of the Cotonou agreements (cooperative strategies). In its general approach, the Cotonou agreement recognizes the cooperation of regional integration as fundamental principles of an EPA. ${ }^{6}$

These measures are applicable to a wide range of functional and thematic areas 
that range from socio-economic infrastructures to promotion and establishment of a regional dialog in the prevention and management of conflicts, human rights, democratization, environment, health, education, research and technological development, disasters preparedness and mitigation.

So, the strategy of the European Union is to build trade agreements that use regional integration as a main basis for the revitalization of West African trade. This reflects the fact that the failure of the previous commercial cooperation agreements, contained in previous trade conventions (Yaoundé and Lomé) is partially due to the heterogeneity of levels of development and the limited markets of West Africa Countries. Regional integration is therefore the basis necessary for, at once, harmonizing the levels of development and provide markets sufficiently attractive to the foreign capital and the domestic capital.

If this intention is laudable and promising in itself, its application raises important questions. Although the renewal of the processes of regional integration in Africa can be beneficial in the processes of negotiations of an EPA, we should not forget, that it means, also, the failure of the previous processes of regional and sub regional integration in Africa, included in West Africa .So, it is appropriate to analyze the ability of an EPA West, Africa- European Union ,to boost the trade in west Africa through the relevance of its application and considering the result of experiments of integration processes (past and recent) of the region.

The question that arises in this section is (to see or to know) if this philosophy can be realized in the framework of an EPA between the western Africa region and the European Union.

\section{A. The Relevance of the EPA Approach towards the Regional Integration Process in West Africa}

Regarding the facilitation of the West African regional integration, the contribution of an EPA, West Africa -European Union, will depend on the configuration of the final provisions of the agreement. The general provisions of the Cotonou Agreement let plane some doubts about the effectiveness of the objectives assigned to EPA in the field of regional integration. Upon completion of negotiation of the EPA, considering the diverse characteristics of the economies of West Africa which could lead to a situation where four types of trade arrangements with the European Union would cohabit in the region: the EPA agreements, "All

${ }^{6}$ For more information regarding the importance of regional integration for the EPAs, see, for example Bilal (2007) in Laport, Geert, insert 2- page 81. 
except Weapons" (AEW) agreements, the generalized preferences system improved agreements, an alternative FTA in the EPAs (which remains to define). The Cotonou agreement allows to the LDC countries to keep their AEW agreements (see chapter 2, article 37 "new trade agreements"). To the non LDC Countries, it allows the conclusion of trade agreements with European Union, others than the EPAs, remaining to be defined, or conclusion of trade agreements under the generalized preferences system improved in Europe. These concerns remain even if, otherwise, the Cotonou Agreement underlines the need to strengthen the capacities of ACP countries least advanced and islandes to participate in the regional integration. ${ }^{7}$

If such eventualities are realized, they will worsen the process of regional integration in West Africa. This concern seemed to gradually dissipate with the offer made by the European Union in March 2007. In fact, during experts' meetings of the European Union and of West Africa, between March and April 2007, the European Commission has offered the opportunity of a total access (not conditioned) to the european markets for the ACP imports, despite the objections of several member states.

The risk of implosion of the regional ECOWAS by implementing an EPA with the European Union thus seemed to go away with these opportunities. But the signature of the intermediate agreement by Ivory Coast and Ghana, after strong political pressures, rests the question with much more acuity. What is worrying in the way of doing of the European Union, it is to cause the disintegration of the regional solidarity thus reducing the confidence in the regional integration as a development tool. For a regional process already worsened by the many breaches in texts, mostly against the Ivory Coast, this signature can only consolidate the authors of the blockings. It would not have raised major problems if a certain maturity existed on the subject or could be quickly envisaged, but it is not the case.

Equally worrisome, is the low importance given by the EPA executives negotiating to the renewal of the integration process in Africa. Since the beginning of the year 1990, Africa, as a whole, attempts to renew its regional integration process that led initially by the redefinition of the legal and institutional frameworks for the regional integration initiatives. They continued by the definition of a common conception of the priorities for the development of Africa,

\footnotetext{
${ }^{7}$ Moreover, the CAP VERDE required to rather sign an agreement of association with the European Union than to be subjected to an EPA between ECOWAS and European Union.
} 
led by the will to establish a set of integrated programs for realizing these priorities (NEPAD). They ended to the setting in prospect for the construction of regional economic blocks like instrument for the economic and social development of Africa (Treaty of Africa Union). In West Africa, the renewal of the regional integration process is conducted in coordination with a program to accelerate the process of regional integration within ECOWAS. However, the approach to the establishment of an EPA does not pay the necessary attention for this phenomenon. It even tends to weaken the bases as far as agreements were signed and are individually signed with countries (Morocco, South Africa, Madagascar, Mauritius, Ivory Coast, Ghana....) Doing so, it is all the efforts towards convergence and harmonization of the rules, on different regions, which are called into question.

\section{B. Regional Integration and Development in West Africa}

We cannot say, given the results of the past experiments that the initiatives of regional economic integration in West Africa, in particular those concerning the period 1960-1990, have postered the development of the countries in this region. Indeed, a quick glance at the intra-community trade shows that they remain below $15 \%$ of their total trade. When the share of intra-regional trade in the WAEMU and the ECOWAS in their total is compared to that of the European Union, we can see all the drama and the difference between these two regions (see figure 1 in annex). But the error to be avoided at this level is to believe that to transfer within ECOWAS mechanisms and legal and institutional arrangements that have made the results of European construction will be enough to make the success of the EPA project. $^{8}$

So the question is why the countries of the West Africa Region they have failed to achieve their goals of integration within the ECOWAS and the CEAO? In the economic literature, beyond the regional differences, the poor performance of the economic integration initiatives of the first wave, between the developing countries, is explained by three main groups of factors: ${ }^{9}$ the structural characteristics of the countries and/or the regions, the deficiencies in the program development, the political lack of will. It is true that the economic factors of creation and trade misuse remain important, but we must be recognize the

\footnotetext{
${ }^{8}$ Moreover, the Cap-Verde required to rather sign an agreement of association with the European Union than to be subjected to an EPA between ECOWAS and European Union.

${ }^{9}$ For a detailed presentation of these factors, see for example World Bank (2000) and BAD (2000).
} 
Figure 1. Compared Evolution of the Intra-trade Shares in the Grand Total Exchanges of the EU (15), ECOWAS and WAMU (1970-2004)

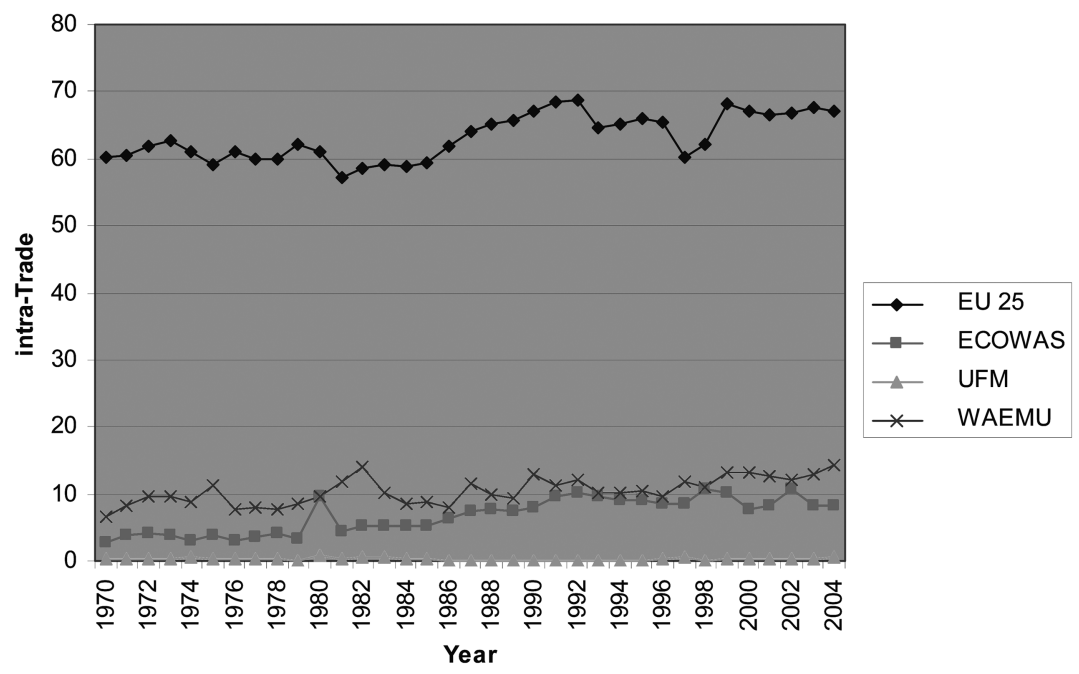

importance of the noneconomic factors in any successful economic integration. In fact, the current state of the regional and sub regional construction in West Africa presents many obstacles of social and political nature resulting in a lack of political will. These observations are the manifestations of an absence of integration and development of culture ${ }^{10,11}$ of political leaders, of intellectuals, of the population. The illustrations of this lack of cultural integration and development are numerous in the West Africa Region and is characterized by frequent violations, continuous and deliberated of the texts. From this point of view, the challenge of an EPA between West Africa and European Union is creating a culture of integration and development.

Besides these reserves on the strategic aspects of the question, we note that the European Union began this stage in its construction from 1986 only, although it was a custom union since 1968. This phase of integration is called "deepening" or "consolidation of the internal market". It raises problem because the ECOWAS is not yet a market requiring to be consolidated by the removal of the obstacles bound to the differences of the national politics of investment and competition, for

\footnotetext{
${ }^{10}$ The culture of integration can be understood as the ability to identify business opportunities that exist in their region, to create them, to exploit them for the benefit of the region, but while recognizing that their exploitations are not the sole responsibility of its nationals.

${ }^{11}$ The culture of development may be understood as the ability to identify business opportunities that exist in the country, to create and to exploit to its advantage but also for the benefit of the country's economy.
} 
example. There is simply a lack of capacity of the current regional market to get organized and to face a competition to benefit from the reciprocity.

In summary, an EPA based on the regional integration in West Africa requires time to reach its development objective.

\section{Joint Integration and Development of the West Africa}

Many arguments exist in favor of economic integration between industrial nations and developing countries. The works of Venables (1999 and 2000) gives a theorization simple and easy to understand. The main argument in favor of mixed integration is that all the partners countries are winners because of the specialization according to the principle of the comparative advantage. The fact of having in the same regional economic block, economies whose domestic price ratio frame with the world price structure, so that each one of these countries will specialize in the production of goods in accordance with its comparative advantage.

The problem with this thesis is that it ignores the negative effects that can create the balance of power between partners, in this case. If Mexico seems to benefit from the implementation of NAFTA (North American Free Trade Agreement) nevertheless NAFTA is asymmetric. However, nothing says that all the developing countries would like to get into this situation. Otherwise, the mixed generation, which by definition is discriminatory, has no economic justification, given that multilateral liberalization would provide for the West Africa Countries higher profits with the same risks (the future of the agricultural peripheral economies).

Besides, the results of the agreements between ACP Countries and the European Community cannot be called successful. On the contrary, these agreements based on non reciprocal trade preferences, have not allowed neither the diversification of the ACP exports (an exception with the Mauritius Island), or retain their markets shares in face to competitors and no more on the world market.

Remember the three important lessons learned from the cooperation ACP countries - European Union, of Yaoundé to Lomé, IV bis, who have formed a triple restriction of the old commercial cooperations. Firstly, the trade cooperation ACP European Union has been considered limited in its ambitions. It was completely focused on the promoting trade between ACP Countries and European Union and has neglected the potential offered by the domestic, regional and international markets. Then, the trade cooperation ACP-European Union had been too limited in its application. The importance of the customs tariffs in the trade decreases 
gradually, while non tariff measures, sanitary and phytosanitary measures protection the environment, the human and animal health are of increasing importance. Moreover, the trade preferences are not granting a comparative advantage, on the preferential market but they do not automatically generate business. They only offer opportunities but have no impact if the country recipient is unable to grasp them: it means, if the production capacities of the ACP countries remain insufficient. Finally the trade cooperation ACP - European Union has been too limited in its perception. It was mainly seen as en end in itself, simply aiming to increase exports of the ACP countries to European Union.

It is hardly noticeable, in practice, that an EPA between West Africa - European Union - takes into account these limits, so much the dimension of conformity with the WTO rules is used for the sole purposes of commercial liberalism.

\section{Developing West Africa by Trade}

Beyond the carried out reflections, above, it should be noted that the EPA and the program of Doha have a common wish to use the trade as an engine for the economic and social development of the developing countries like of West Africa.

This raises the question of the relationship between Trade and Development. In particular, to know if the trade policies such as those of WTO or those of the EPAs may be effective in terms of development for Africa in generally, for West Africa particularly.

In the specialized literature, different answers were given to this question from which we may identify four major trends: that of the liberalization, of the dependence, of the technological independence and that of the institutional development. In this work, all these trends are not discussed, only those concerning the liberalization and the institutional development.

\section{A. The Efficiency of Free Trade Policies in Africa}

The justification of a multilateral open trading system worldwide, let us remember it, is based on the acceptance of the existence of a statistical link between trade liberalization and economic growth. The explanation of this relationship, in theory, is based on the principle of comparative advantage of Ricardo and his developments. The question, we can ask, is to know the value of this relationship for the African countries, in particular those of West Africa, given the structural characteristics of their economies. 
According neo-classic, the development of Africa goes through the development of its international trade (intra and inter). To reach this goal, Africa must adopt liberal trade policies: see (World bank; 2000, Sachs and Warner; 1997, Collier and Gunning; 1999 and, Subramanian and Tamirisa; 2001). The argument used is as follows: with the observation and analysis, the developing countries that manage to reach an higher growth and lift their people out of the poverty have one thing in common: they have opened their economies on the outside within the framework of a strategy development based on the ideas of improvement of the conditions of the investment an reduction of the poverty.

In the case of Africa, this argument takes the following form: The african markets have been distorded due to the introduction of restrictive trade policies. Any reform of the trade policies to recommend and to implement in Africa should move in the same direction "the establishment of "true prices" within countries, between countries and with the rest of the world. Their argument is simple. The African countries because they have applied for protectionist trade policies since decades, have also created distorsions in the functioning of their markets. Those have prevented their economies from benefitting fully at the same time from the different increases of the global demand, of transfers of technologies which ensure the exchanges and flows of Foreign Direct Investments (FDI), base of any sustainable economic development. In these protectionist conditions, invest in Africa offers indeed, the prospects for lower profits that in the other part of the world (of the development world, in particular).It is thus the application of protectionist trade policies which justifies the increasing marginalization of Africa. This lack of major inflows of Foreign Direct Investments explains then why Africa has not be able to diversify its production and exports, even in the field of rough materials.

The consensus on what constitutes a reasonable trade strategy for the countries of Africa would be: demonopolize the trade, to simplify the quantitative restrictions by tariffs, to reduce the formalities, to implement transparent customs clearance procedures, to replace the quantitative restrictions by tariffs, to avoid drastic fluctuations of the tariffs rates, not of impose excessively high rates for an effective protection, granting the exporters a free access to imported inputs, to refrain from manifesting an attitude hostile to export, not to impose excessives taxes on exports Rodrik (1998).

To benefit from the trade opening, in this regards, will ask to Africa many efforts. ${ }^{12}$ These challenges fall into two categories: the challenges within each 
country and the challenges outside the countries. The internal challenges start from the structural reforms to the coordination of the political economies and by establishing socio-economic infrastructures of quality. The external challenges include two dimensions: one regional and one global. In their regional dimension, the challenges which arise in Africa are the institutional incoherence due to the existence of too many Inter Governmental Organization, the existence of informed economic network and the proliferation of internal conflicts with the strong regional trends.

The global dimension of the external challenges is formed by the arbitration between the need to build strong regional economies and to build Countries with strong economies. The globalization, because it delites the borders of the Nations complicates the task of Africa, singularly to take up these challenges. The costs of such reforms then constitute a serious obstacle to effective application of such policies in Africa in general, in West Africa in particular.

However, it should be underline the availability, in theory, of the European Union to finance the upgrading of enterprises of West Africa and the development of its economies by the regional EPA funds. But, it is not enough to answer to the problem of taking into account of the development dimension in the EPA. Considering the development needs of each ACP regions, it is allowed to doubt of the ability of the European Union to being able to ensure, sole, these financial efforts. So, would it have been indicated, for a question of adequacy of financial means to the financial needs of the ACP countries in general, those of West Africa in particular, that the introduction of the reciprocity is bound to the ability of each region to assume a substantial part. In this context, the rhythm and the intensity of the opening should have been conditioned by the financial capacity of the regions and their level of solidarity. Given the level of economic development in the West Africa region and the status of the construction of regional and sub-regional economy, it is surprising that such an approach would lead to a planned opening of $80 \%$ of their global exchanges over a period of less than 12 years. Probably that the prospect of a long term reciprocity has led to the decision by the European Union for the present patterns of opening of global trade of ACP regionalised.

Beyond these considerations, the question of the existence of a positive statistical relationship between trade, economic growth and development, is posed by many authors.

${ }^{12}$ See Word Bank (2000) and Njinkeu (2004) for details of these challenges 


\section{B. The Relevance of the Primacy of Institutional Reforms}

To the liberal thesis, opposes today that of the upholders of institutional primacy. According to those, trade liberalization is not sufficient as a solution to the marginalization of Africa and its underdevelopment (Foroutan and Pritchett; 1993, Coe and Hoffmaister; 1999, Rodrik; 1998, Stiglitz; 2003, Rodrik and Subramania; 2003, Charlton and Stiglizt; 2007), because any development is preceded by an institutional development first. In particular, it is true that the trade opening of the Asian countries was them beneficial; it was preceded by major institutional reforms that have made them able to benefit from it. Thus, these authors call into question the existence of the statistical relationship between trade opening and economy development even beyond difficulties resulting from the measures in the sense of Siroën (2000). They offer, in return, major institutional reforms prior any liberalization of the exchanges or liberalization targeted at the sectors where effective institutions already exist.

The argument of the upholders for the primacy of the institutional reforms can be so summarized: the institutions and authorities of each economy determine the levels of gains that a country, a region can draw of its trade. This is possible because the nature of the institutions and the quality of the authorities have an influence on the costs (natural and non natural) of the trade opening, the nature of the profits and their assignments (efficiency and equity). So, in the absence of institutions and authorities of quality and suitable the trade opening, in particular, the liberalization of the trade may not be beneficial to the country.

Under the EPA, the question of institutional reforms can be understood in terms of morality and equity one hand and efficiency on the other hand. Regarding the question of the morality and equity of the financing, the whole is not to conceive effective financial mechanisms for the development and the necessary financial capacity; it must take also into account the legal and human conditions of this financing. The West Africa countries are marked by high political instabilities. The tribal and ethnic management of the power, the multiplication of national conflicts to regional tendency, (Sierra-Leone, Liberia, Côte d'Ivoire, Togo and the persistence of social, political and military tensions at the borders and inside of Guinea, the rebellions in Niger, in Mali, etc...) with their batches of the Human Rights violations, (kidnappings, tortures, rapes and impunities). How to match the financial needs for the development of these countries with the requirements of the International Community in respects of the Human Rights and the protection of the 
Human Life? If the conditionalities of funding are determinated by the standard of protection of the Human rights, in these conditions, little even no countries could benefit from such funding. The question arises then differently in terms of effective financing mechanisms.

Regarding the effectiveness of the mechanisms for financing the development, it should be noted that the economies of the West Africa region have strong institutional rigidities. They start from poor political governance, state and corporate with the non straightforward application of existing rules and laws, to the fraud, the counterfeiting, the galloping corruption, the organized racketeering, the right not said, or a total absence of legal and institutional frameworks favourable to the business. A policy of trade liberalization under these conditions would be probably beneficial to the predation rentier of Oligopolies or Monopolies. That would involve he transformation of these countries in peripheral markets of consumption.

The solution to this situation is creating a culture of development and integration. So, from an institutional perspective, it would be surprising that the establishment of an EPA between the West Africa region and the European Union allows the development of the economies of West Africa in actual conditions.

\section{Conclusion}

An EPA between the West Africa Region and the European Union seems to present, in its formulation and its objectives, many opportunities for the countries of West Africa, because of the importance that it wants to give to the development aspect. However, the analysis of the mechanisms by which the EPA will make the development of the countries of West Africa shows the importance of the challenges so that these countries can benefit from it.

These challenges are at several levels: in the conception, in the process of implementation an in the effectiveness in practice. They have their own specificities to the interaction between EPAs, multilateral trade liberalization, regional integration and the use of trade as an engine of development. All the question is to know, given the processes of multilateral liberalization of trade, the processes of regional, sub-regional integration, the structural and institutional rigidities, if the countries of West Africa can master the complex interactions that it creates and the efforts required to take advantage of the implementation of an EPA between the West Africa region and the European Union. 
In our opinion, the countries of West Africa will be able to benefit from the establishment of an EPA with the European Union, only if it allows them to create a culture of integration and development. That would imply from a political perspective the financing of the development first, before any commitments to reciprocal trade liberalization of their exchanges with the European Union.

The EPA negotiations between West Africa and European Union make them jog two major risks today: 1) stopping the process of regional integration which is a threat, more and more precise and 2) the transformation within 15-20 years ahead of the economies of the region in peripheral markets of consumers.

So the urgency today, for the West Africa Countries is to come together to defend their interests and those of the region in the forums of the WTO and the EPAs; Otherwise, they will be once moreover, the losers of the agreements with the principle of irreversibility becoming more assertive.

Received 6 June 2009, Revised 13 January 2010, Accepted 15 January 2010

\section{Appendix}

Table 1. Index of Development Comparison West Africa and European Union (from 1992 to 2004)

\begin{tabular}{ccccccccc}
\hline Year & 1992 & 1999 & 2000 & 2001 & 2002 & 2003 & 2004 \\
\hline $\begin{array}{c}\text { FDI } \\
\text { (thousand } \\
\text { dollars) }\end{array}$ & EU & 2.261 .8 & 4.657 .9 & 5.497 .1 & 5.963 .8 & 6.981 .0 & 8.940 .8 & 9.891 .2 \\
& EU & 87.8 & 137.0 & 143.5 & 145.0 & 155.6 & 167.1 & 177.0 \\
$\begin{array}{c}\text { Population } \\
\text { (million) }\end{array}$ & WA & $188,790.9$ & $227,761.7$ & $233,619.2$ & $239,518.8$ & $245,464.1$ & $251,459.5$ & $257,513.0$ \\
$\begin{array}{c}\text { GDP by } \\
\text { inhabitant } \\
\text { (dollars) }\end{array}$ & EU & $21,321.9$ & $22,827.4$ & $21,005.5$ & $21,049.3$ & $22,833.0$ & $27,695.7$ & $31,742.2$ \\
$\begin{array}{c}\text { Density } \\
\text { (inhabitant } \\
\text { by square }\end{array}$ & EU & 1139.7 & 341.7 & 368.6 & 375.6 & 385.4 & 460.4 & 459.0 \\
kilometre) & 30.8 & 37.1 & 38.1 & 39.0 & 40.0 & 41.0 & 42.0 \\
\hline
\end{tabular}




\section{References}

Bilal, S.(2002), "Implications of the Doha Development Agenda on the EPA Negotiations", Seminar on the EPA, October 31-November 1, COMESA Secretariat, Lusaka, Zambia.

Bilal, S.(2007), "Vers une Redéfinition des Relations Commerciales ACP-UE: les Accords de Partenariat économique.", dans L'Accord de partenariat de Cotonou: Quel rôle dans un monde en mutation? Réflexions sur l'avenir des relations ACPUE, Rapport ECDPM 13 sous la direction de Laport.

Cedeao(2004), "Feuille de route agrée des négociations de l'accord de partenariat économique entre l'Afrique de l'Ouest et la Communauté Européenne", Réunion Technique conjointe CE-CEDEAO de négociation de l'Accord de partenariat économique, mars, Abuja (Nigeria).

Charlton, A. et J. E. Stiglitz(2007), Pour un commerce mondial plus juste, Traduit de l'anglais par Paul Chemla, Nouveaux Horizons.

Coe, D. and A. Hoffmaister(1999), "North-South Trade: Is Africa Unusual? ”, Journal of African Economies, Vol. 8, $N^{o}$ 2, pp. 228-256.

Collier, P. and A. J. Venables(2007), "Rethinking Trade Preferences: How Africa Can Diversify Its Exports", The World Economy, Journal Compilation, pp. 1326-1345.

Collier, P. and W., Gunning(1999), "Africa's Economic Performance”, Journal of Economic Literature, Vol. 107, pp. 64-111.

Courrier(2000), Accord de Partenariat ACP-CE signé à Cotonou le 23 juin 2000, Edition spéciale, septembre.

Foroutan, F.(1995), "Regional Integration in Sub Saharan Africa: Past Experience and Future Prospects", In New Dimension in Regional Integration, de Melo and Panagariya eds., Cambridge University Press, pp 234-269.

Foroutan, F. and L. Pritchett(1993), "Intra-Sub-Saharn African Trade: Is It Too Little?", Journal of African economics, vol. 2, pp.74-105.

Gemdev(2000), La Mondialisation: les mots et les choses, Paris Karthala.

Laport, G.(2007), L'Accord de partenariat de Cotonou: Quel rôle dans un monde en mutation? Réflexions sur l'avenir des relations ACP-UE, Rapport ECDPM 13, novembre.

Manuel 2 des Statistiques de la CNUCED en ligne; 2005.

Njinkeu, D.(2004), L'Afrique et les défis de l'OMC, Karthala.

Ochieng, C. M. O(2007), "The EU-ACP Economic Partnership Agreements and the 'Development Question': Constraints and Opportunities Posed by Article XXIV and Special and Differential Treatment Provisions of the WTO", Journal of International Economic Law, Vol 10, $N^{\circ} 2, p p .363-395$.

OMC(2003), Comprendre l'OMC, Secrétariat OMC, Genève (Suisse).

OMC(2003), La déclaration de Doha: Programme de Doha pour le Développement, Secrétariat OMC, Genève (Suisse).

OMC(2003), Les Textes juridiques. Résultats des Négociations commerciales 
multilatérales du Cycle d'Uruguay, Secrétariat OMC, Genève (Suisse).

OMC(2004), Programme de travail de Doha. Décision adoptée par le Conseil général le $1^{\text {er }}$ août 2004 (WT/L/579).

PNUD(2003), Rapport sur le développement humain. Les objectifs du Millénaire pour le développement: un pacte entre les pays pour vaincre la pauvreté humaine, Economica, Paris

Rapport conjoint relative à l'état d'avancement de la négociation des APE, Comité technique conjoint de suivi ACP-CE (2004), Bruxelles (Belgique), 25 Octobre, ACP/ 00/018/04 Rev.1.

Regnault, H. et C. Deblock(2006), "Les Enjeux Théoriques de la Reconnexion NordSud", dans Nord-Sud. La reconnexion périphérique, sous la direction de Regnault et Deblock, Editions Athéna.

Rodrik, D.(1998), "Trade Policy and Economic Performance in Sub-Saharan Africa", EGDI Studies in brief, $N^{\circ} 1 / 98$.

Rodrik, D. et A. Subramanian(2003), "La Primauté des Institutions: ce que cela veut dire et ce que cela ne veut pas dire”, Finances 1 Développement $N^{\circ} 2$, volume 40, juin.

Rodrik, D.(2000), Can integration into the world economy substitute for a development strategy?, Conférence de la Banque Mondiale ABCDE-juin 2000.

Sachs, J. and A. Warner(1997), "Sources of Slow Growth in African Economies", Journal of African Economies, Vol. 6, pp. 335-376.

Siroën, J-M.(2000), “L'ouverture Commerciale est-elle Mesurable?", Colloque Ouverture économique et développement, Tunis, 22-23-24 juin 2000.

Subramanian, A. and N. Tamirisa(2001), "Africa's Trade Revisited", IMF Working Paper, $W P / 01 / 33$.

Wordl Bank(2000), Trade Blocs, World Bank and Oxford University Press.

World Bank(2002), Development, Trade, and the WTO, edited by Hoekman B. Aaditya Mattoo, and Philip English. 